\title{
A Framework of All Discovered Immunological Pathways and Their Roles for Four Specific Types of Pathogens and Hypersensitivities
}

\author{
Wan-Chung $\mathrm{Hu}^{*}$ \\ Department of Clinical Pathology, Taipei Tzu Chi Hospital, Buddhist Tzu Chi Medical Foundation, New Taipei City, Taiwan
}

Keywords: Th1/2, Th3, Tr1, Th17, Th9, Th22, Treg, Tfh

\section{BACKGROUND OF HOST IMMUNE RESPONSES}

Although a number of host immunological pathways have been discovered including the traditional TH1/TH2, TH3, TH17, TH22, Tfh, Treg, TH9, and $\operatorname{Tr} 1(\mathrm{TH} \alpha \beta)$ pathways, they are not logically organized. In this article, I have described a detailed and complete picture of the host immunological pathways (Figure 1).

The traditional TH1/TH2 paradigm was proposed by Mosmann in 1986 (1). TH1 responses were considered to provide host immunity against intracellular pathogens such as viruses, intracellular bacteria, and protozoa whereas $\mathrm{TH} 2$ responses were considered to provide host immunity against multicellular parasites (helminths). In my $\mathrm{PhD}$ thesis, I proposed a new $\mathrm{TH} \alpha \beta$ immunological pathway against viruses, derived from the traditional TH1 responses (2), which is associated with intracellular bacteria and protozoa. The TH3 and Tr1 immunological pathways were identified after TH1 and TH2 $(3,4)$. Additional immune responses including the TH17, TH22, Tfh, Treg, and TH1-like immunological pathways have been discovered recently (5-7).

\section{Initiatory Immune Response}

Follicular helper T cells (Tfh) are considered as the key helper cells for B-cell germinal centers in lymph nodes and are characterized as IL-21-producing T cells (8). Follicular dendritic cells (CD14+) are antigen presenting cells (9), whereas lymphoid tissue inducer cells (LTi) are the innate lymphoid cells for Tfh (10). BCL6 is a key transcription factor in Tfh development (11). TGF- $\beta$ induced by a STAT5 signal can constrain the differentiation of IL-21-producing helper T cells (12). IL-21 production is related to STAT1and STAT3 activation. IL-21 production is also related to STAT5 activation because immunosuppressive prolactin can cause STAT5a to suppress BCL6 expression (13). In contrast, STAT5b can upregulate BCL6 (14). STAT5a and STAT5b have distinct target genes in immune responses (15), and STAT5b is the transcription factor that induces Tfh. Tfh can induce B-cells to produce IgM antibodies and IL-21 produced by Tfh facilitates B cell isotype switching to $\operatorname{IgG}(16,17)$. Besides the protein antigen recognized by $\mathrm{B}$ cells and $\mathrm{T}$ cells, natural killer T (NKT) cells also recognize lipid antigens. The subtype iNKTfh plays a role in Tfh responses (18). Thus, T lymphocytes are the first to initiate adaptive host immunity (19-21), wherein different STAT proteins regulate different immunological pathways. If the infection tends to be eradicable, then the host immunological pathways mentioned in the following sections are generated along with other cytokines.

\section{Eradicable Immune Responses}

TH1 immune responses are driven by IL-12 and are induced against intracellular bacteria or protozoa (22). Type 2 myeloid dendritic cells $(\mathrm{CD} 141+\mathrm{mDC} 2)$ are the antigen presenting cells 


\section{Eradicable}
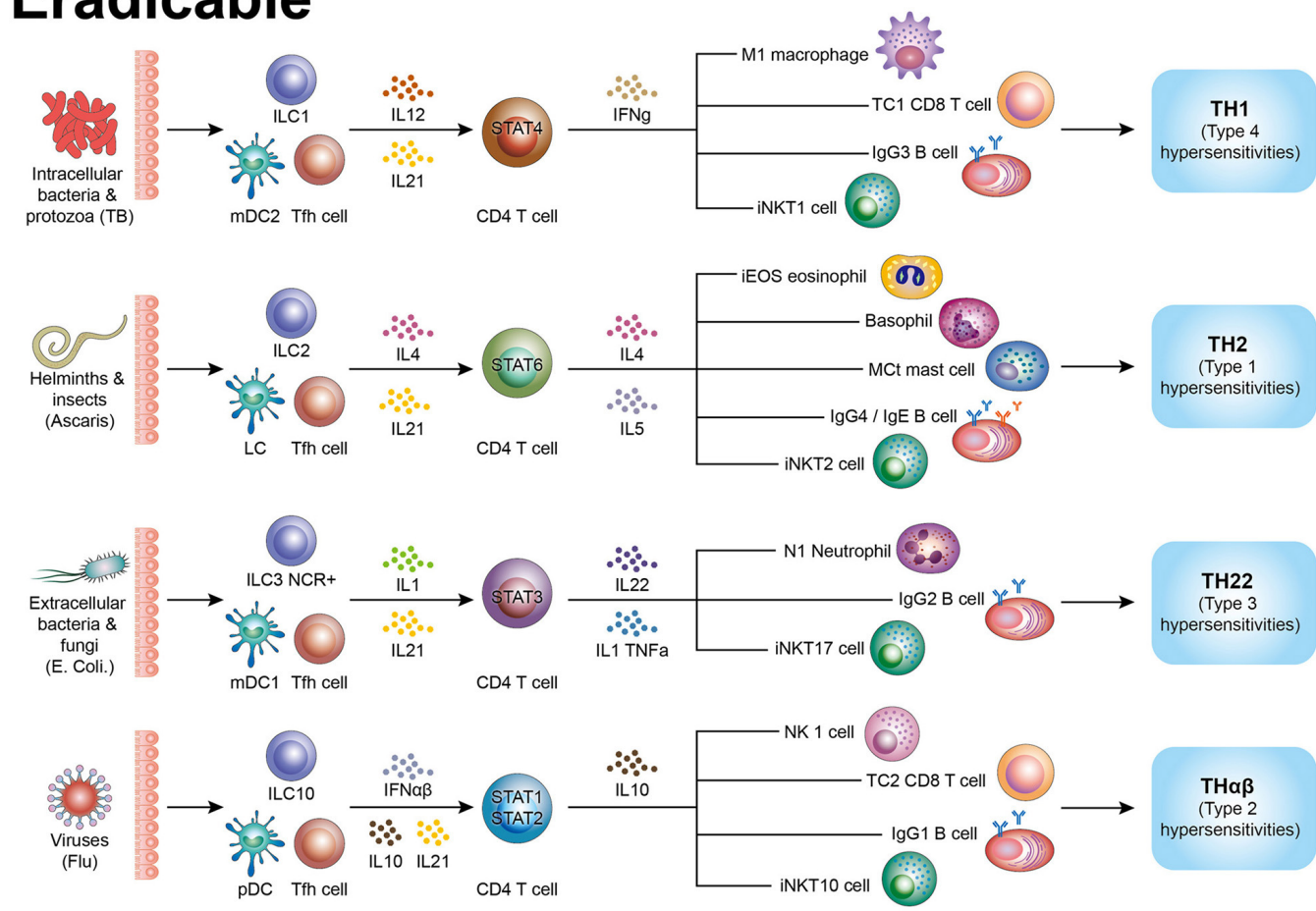

\section{Tolerable}
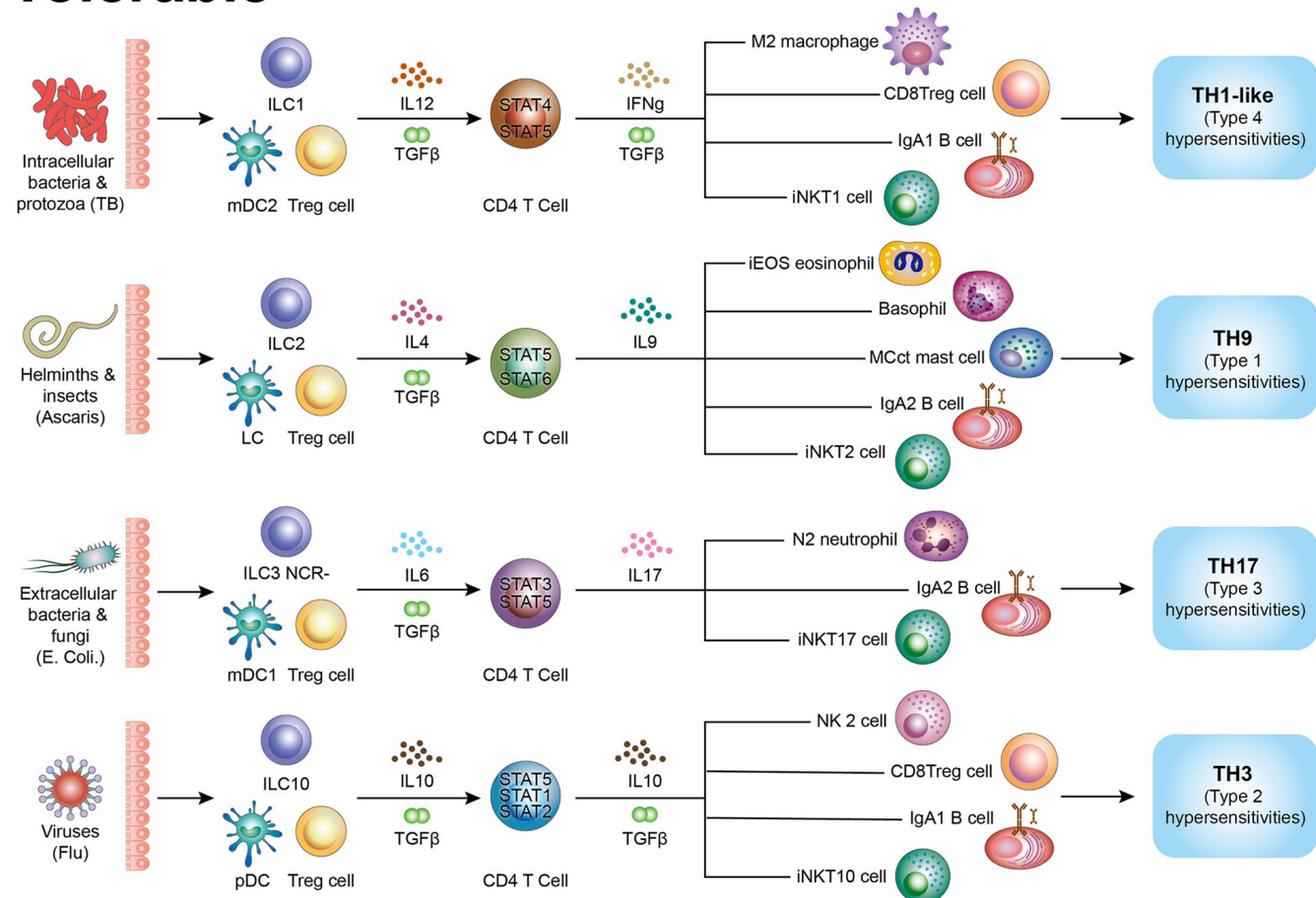

FIGURE 1 | Summary figure of host immunological pathways. Tfh side (follicular help T cell) initiates initiatory immunity and the Treg side (regulatory T cells) initiates regulatory immunity. Eradicable immune responses include TH1, TH2, TH17, and TH $\alpha \beta$. Tolerable immune responses include TH1-like (Th1 L), TH9, TH22, and TH3. The picture shows all effector cells associated the types of host immune responses. TH1/TH1-like are immune responses against intracellular bacteria/protozoa and are related to type 4 hypersensitivities. TH2/TH9 are immune responses against helminths and are related to type 1 hypersensitivities. TH17/TH22 are immune responses against extracellular bacteria/fungi and are related to type 3 hypersensitivities. TH $\alpha \beta / \mathrm{TH} 3$ are immune responses against viruses and are related to type 2 hypersensitivities. 
in the TH1 response (9). The main TH1 effector cells are stimulatory macrophages (M1), IFN- $\gamma$-secreting cytotoxic CD8 T cells (CD28+ Tc1), IFN- $\gamma$-secreting CD4 T cells, iNKT1 cells, and IgG3-producing $\mathrm{B}$-cells $(23,24)$. Initiation of eradicable immunity also requires innate lymphoid cells to produce the initial cytokines that drive different immunological pathways. For TH1 immune responses, the key innate lymphoid cells are ILC1 (25). STAT4 is the key transcription factor for TH1 immunity but T-bet also plays a vital role. TH1 responses against self-antigens present as type 4 delayed-type hypersensitivity, such as type 1 diabetes mellitus or Crohn's disease (26).

TH2 immune responses are driven by IL- 4 and is induced against extracellular parasites (helminths) (27). The antigen presenting cells in $\mathrm{TH} 2$ immune responses are Langerhans cells $(\mathrm{CD} 1 \mathrm{a}+)(9,28)$. The main TH2 effector cells are eosinophils (iEOS), basophils/pro-inflammatory mast cells (MCt, mast cell tryptase), IL-4-/IL-5-secreting CD4 T cells, iNKT2 cells, ILC2, and IgG4/IgE-producing B-cells (29). IgG4 activates eosinophils, and IgE activates mast cells, as in acute anaphylaxis (30). IgG4eosinophils function to activate eosinophil-mediated cellular immunity against parasites or insects, whereas IgE-mast cells act to expel helminths or insects through a physiological mechanism. Mast cells activated by IgE can release histamine, which causes bronchoconstriction, vomiting/nausea, rhinorrhea, skin itching, gastric acidification, increased local vascular permeability, or increased bowel movement. These actions can all help to physiologically expel helminths or insects. The key transcription factor in TH2 response is STAT6 and GATA3 also plays a vital role in the $\mathrm{TH} 2$ immunological pathway. $\mathrm{TH} 2$ responses against selfantigens present as type 1 immediate allergy, such as food/drug allergy, anaphylaxis, or urticarial (31).

$\mathrm{TH} \alpha \beta$ is distinct from traditional $\mathrm{TH} 1$ immune responses (2). TH $\alpha \beta$ cells are induced against viruses and were previously called as $\operatorname{Tr} 1$ cells $(4,32)$. TH $\alpha \beta$ immune responses are driven by IFN $\alpha / \beta$ or IL-10. The antigen presenting cells for $\mathrm{TH} \alpha \beta$ responses are plasmacytoid dendritic cells (pDC) (9). The main effector cells of $\mathrm{TH} \alpha \beta$ immune responses are IL-10-producing stimulatory NK cells (CD56-CD16 + NK1 cells), IL-10/IL27-secreting CD4 T cells, IL-10-secreting cytotoxic CD8 T cells $(\mathrm{CD} 28+\mathrm{Tc} 2)$, iNKT10 cells, ILC10, and IgG1-producing Bcells $(23,33-35)$. The CD27 molecule is important for antiviral immunity. The key transcription factors for $\mathrm{TH} \alpha \beta$ response are STAT1 and STAT2 (36). TH $\alpha \beta$ immune responses against self-antigens present as type 2 antibody-dependent cytotoxic hypersensitivity, such as the acute stage of myasthenia gravis or Graves' disease (37). IL-10 is not merely an immunosuppressive cytokine; it can also have potent stimulatory effects on NK cells, cytotoxic T lymphocytes (CTLs), and B-cells.

TH22 responses are part of the host innate immunity against extracellular bacteria and fungi (38). TH22 response is driven by IL-6 or TNF $\alpha$ (39). The antigen presenting cells in TH22 immune responses are type 1 myeloid dendritic cells (CD1c+ mDC1) (9). The main TH22 effector cells are neutrophils (N1), IL-22-secreting CD4 T cells, iNKT17 cells, ILC3(NCR+), and IgG2-producing B-cells $(6,40)$. The key TH22 transcription factor is STAT3; AP1 and CEBP are also important transcription factors. TGF- $\beta$ can suppress IL-22 to skew the TH22 immune response toward TH17 (41). TH22 responses against selfantigens present as type 3 immune-complex and complementmediated hypersensitivity, such as the Arthus reaction or rheumatoid arthritis (42). The host immunological pathways induced are mainly decided by the extracellular or intracellular location of protozoa or fungi.

Four IgG subtypes fit the four types of acute immunological pathways. Murine IgG antibodies also have four subclasses and are correlated with human IgG subtypes as follows: Human IgG1 <-> Murine IgG2a; Human IgG2<-> Murine IgG3; Human IgG3<-> Murine IgG2b; and Human IgG4<-> Murine IgG1 (43). hIgG1/mIgG2a function against viral antigens; hIgG2/mIgG3 function against bacterial antigen, especially polysaccharides; hIgG3/mIgG2b act against intracellular bacteria; and hIgG4/mIgG1 act against parasite antigens (44-46). Notably, the immune response against fungi or protozoa is mainly based on their intracellular or extracellular location. Extracellular fungi such as Candida spp or Aspergillus spp usually trigger TH22 immune responses, whereas intracellular fungi such as Histoplasma spp. trigger TH1 responses.

\section{Regulatory Immune Responses}

Tregs are the host immune inhibitory cells (47) driven by IL-2 and TGF- $\beta$. Regulatory dendritic cells (DCreg) are the antigen presenting cells for Tregs (48). Regulatory innate lymphoid cells (ILCreg) are the initial helpers for Treg production (49). The main effector cells for Tregs are the TGF- $\beta$-producing CD4 T cells, FOXP3 regulatory iNKT cells, and IgA-producing B-cells (50). STAT5, especially STAT5a is the key transcription factor for the Treg pathway. However, both STAT5a and STAT5b play non-redundant roles in Treg generation (51). They may first act sequentially with STAT5b activation in Tfh signaling. Combined signaling STAT5b and STAT5a induces Treg generation. The combination of Tregs and the aforementioned four immunological pathways are important to shift adaptive immunity to tolerable immunity. During initial infection, acutestage fierce cytokines can rapidly kill pathogens and infected cells or tissues. However, if the pathogen infects numerous cells in a tissue such as the liver, killing the infected cells will completely destroy the organ (52). Thus, a regulatory T cell STAT5 signal combined with $\mathrm{TH} 1 / \mathrm{TH} 2 / \mathrm{TH} 22 / \mathrm{TH} \alpha \beta$ will allow the generation of CD4 T cells with less fierce inflammatory cytokines (51). TH1like/TH9/TH17/TH3 immunological pathways are generated during chronic infection. $\operatorname{IgA} 1$ and $\operatorname{IgA} 2$ are the two types of IgA antibodies, with IgA1 being dominant in the serum, whereas $\operatorname{IgA} 2$ is dominant in the mucosa. TGF- $\beta$ can induce IgA1 or IgA2 depending on the lymphoid follicle location (53). In the Gutassociated lymphoid tissues (GALTs) or the Peyer's patches, IgA2 is the dominant IgA antibody produced in the gastrointestinal mucosa. In the lymph nodes at other body locations, IgA1 is the dominant IgA antibody produced. However, IgA1 is specifically related to viral protein antigens, whereas IgA2 is especially related to bacterial antigens such as LPS. The heavy-chain locus sequence of B-cell antibodies on the human chromosome 14 is $\operatorname{IgM}, \operatorname{IgD}$, IgG3, IgG1, IgA1, IgG2, IgG4, IgE, and IgA2. B-cells co-express 
$\operatorname{IgM}$ and IgD. IgG3, IgG1, and IgA1 comprise the first group for cellular immunity, whereas IgG2, IgG4, IgE, and IgA2 can be considered as the second group for humoral immunity. The gene sequence order is important as it affects the time sequence of the isotype switch.

\section{Tolerable Immune Responses}

TH1-like cells (non-classic TH1) are initiated by TGF- $\beta$ (STAT5 signaling) and IFN- $\gamma$ (STAT4 signaling). TH1-like cells with Foxp3+ regulatory characteristics have been identified (7). TH1 helper cells and TH1-like cells are closely related (54). TH1-like cells are induced in chronic $\mathrm{TH} 1 \mathrm{immune}$ responses. Thus, these cells may be related to chronic inflammation such as long-term tuberculosis or leishmania infection (55). The effector cells of TH1-like immune responses include suppressive macrophages (M2), ILC1, suppressive CD8 T cells (CD28-CD8+Treg), IgA1producing B-cells, iNKT1 cells, and IFN- $\gamma$-/TGF- $\beta$-producing CD4 $\mathrm{T}$ cells $(24,40,56)$. The TH1-like response induces type 4 delayed-type hypersensitivity, such as Crohn's disease (26).

TH9 cells are driven by IL-4 (STAT6 signaling) combined with TGF- $\beta$ (STAT5 signaling) (57-59). Thus, TH9 cells are closely related to the TH2 immunological pathway in parasite immunity
(60). The cells are characterized as IL-9-secreting CD4 T cell. TH9 cells are important under a chronic allergic condition such as asthma. Thus, TH9 helper cells are chronic T helper cells related to TH2 immune response. The effector cells of TH9 immunity include regulatory eosinophils, basophils/profibrotic mast cells (MCct, mast cell chymase, and tryptase), ILC2, IL-9-producing CD4 T cells, iNKT2 cells, and IgA2-producing B-cells $(40,61)$. TH9 immune responses present as type 1 allergy, including asthma (29).

TH17 cells are driven by IL-6/IL- 1 combined with TGF- $\beta$ (5). Thus, TH17 cells are closely related to the TH22 immunological pathway against extracellular bacteria and fungi (62). TH17 cells are characterized as IL-17-secreting CD4 T cells. TH17 cells are important in chronic immune-complex-mediated diseases such as rheumatic arthritis. The TH17 helper cell is the chronic T helper cell related to TH22 immunity. TGF- $\beta$ with STAT5 can suppress the acute IL-22-producing cells and enhance the chronic IL-17-producing cells (41). Owing to the role of TGF$\beta$ in TH17 immunity, regulatory IL-17-producing cells have been noted. The effector cells of TH17 immunity include regulatory neutrophils (N2), ILC3(NCR-), IL-17-producing CD4 T cells, iNKT17 cells, and IgA2-producing B-cells (40,

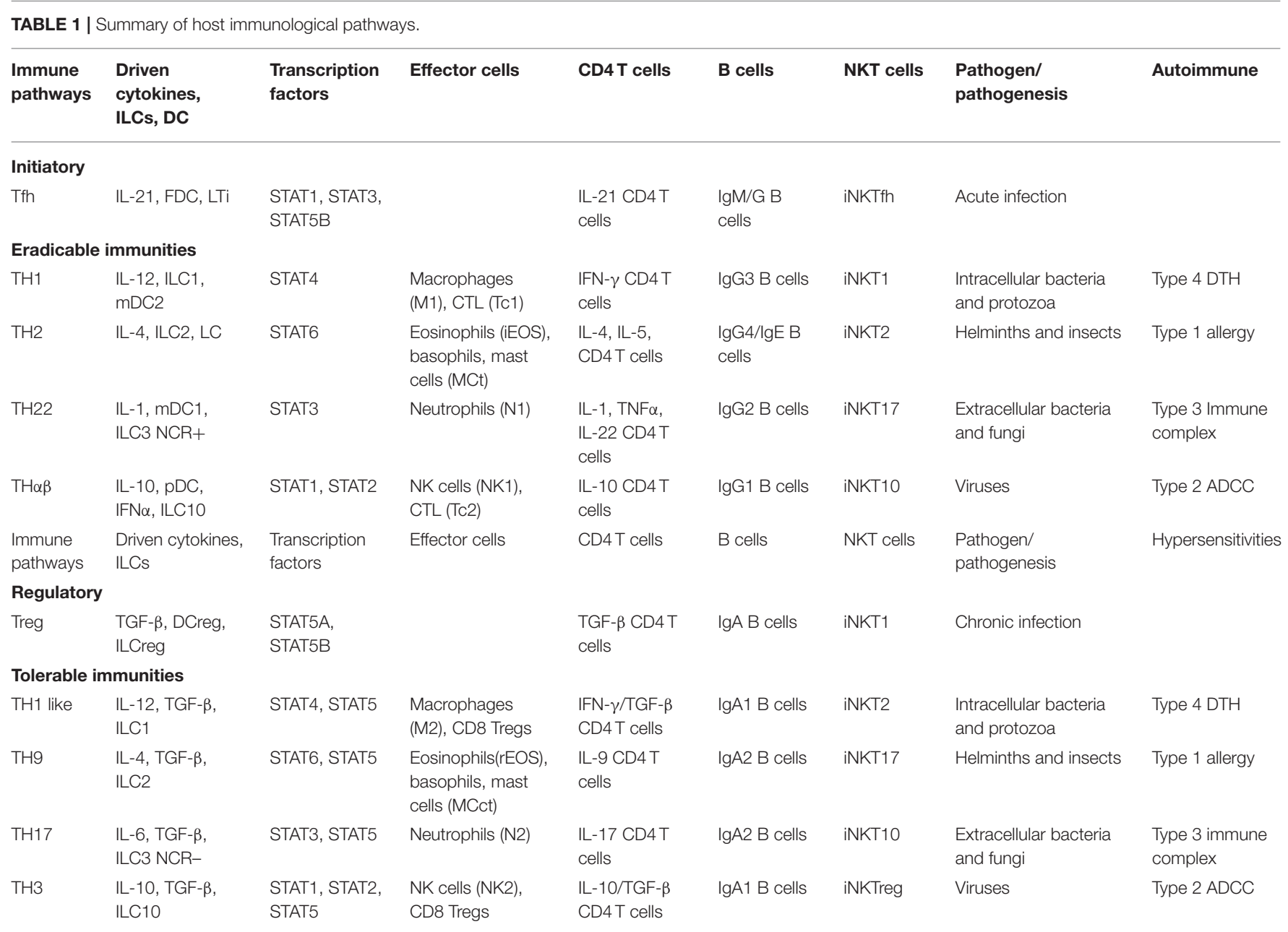


63). TH17 immunity presents as type 3 immune-complex hypersensitivity, including ulcerative colitis or rheumatoid arthritis (42).

TH3 cells are driven by IL-10 and TGF- $\beta(64,65)$. Thus, $\mathrm{TH} 3$ cells are closely related to the $\mathrm{TH} \alpha \beta$ immunological pathway against viruses (66). These cells also produce IL10 and TGF- $\beta$. Thus, TH3 helper cells are important for chronic antibody-dependent cellular cytotoxic hypersensitivity. TH3 cells are the chronic helper $\mathrm{T}$ cells corresponding to $\mathrm{TH} \alpha \beta$ helper cells. The TH3 immune effector cells include IL-13-producing regulatory NK cells (CD56 + CD16-NK2 cells), ILC10, IL-10- and TGF- $\beta$-secreting CD4T cells, suppressive CD8 T cells (CD28-CD8+ Treg), iNKT10 cells, and IgA1-producing B-cells $(34,35,56,67,68)$. IgA1 of TH3 immune responses is produced in the serum and acts against viral protein antigens. TH3 immune responses induce type 2 antibody-dependent cytotoxic hypersensitivity, including the chronic stage of Systemic Lupus Erythematosus (SLE) (69).

\section{CONCLUSIONS}

The summary diagram includes complete picture of the $4 \times 2+2$ immunological pathways (Table 1). The TH1, TH2, TH22, and TH $\alpha \beta$ eradicable immune responses correspond with the TH1-like, TH9, TH17, and $\mathrm{TH} 3$ tolerable immune responses, respectively, and match the four types of hypersensitivities. The detailed immune responses against different pathogens and in allergy/hypersensitivity can thus be understood clearly. This framework can provide new insights for therapeutic agent development for the four types of pathogens and hypersensitivities.

\section{REFERENCES}

1. Mosmann TR, Cherwinski H, Bond MW, Giedlin MA, Coffman RL. Two types of murine helper T cell clone. I. Definition according to profiles of lymphokine activities and secreted proteins. J Immunol. (1986) 136:2348-57.

2. Hu WC. Human immune responses to Plasmodium falciparum infection: molecular evidence for a suboptimal THalphabeta and TH17 bias over ideal and effective traditional TH1 immune response. Malar J. (2013) 12:392. doi: 10.1186/1475-2875-12-392

3. Kumar S, Naqvi RA, Khanna N, Pathak P, Rao DN. Th3 immune responses in the progression of leprosy via molecular cross-talks of TGF-beta, CTLA-4 and Cbl-b. Clin Immunol. (2011) 141:133-42. doi: 10.1016/j.clim.2011.06.007

4. Levings MK, Sangregorio R, Galbiati F, Squadrone S R. de Waal Malefyt and Roncarolo MG, IFN-alpha and IL-10 induce the differentiation of human type $1 \mathrm{~T}$ regulatory cells. J Immunol. (2001) 166:55309. doi: 10.4049/jimmunol.166.9.5530

5. Harrington LE, Hatton RD, Mangan PR, Turner H, Murphy TL, Murphy $\mathrm{KM}$, et al. Interleukin 17-producing CD4+ effector $\mathrm{T}$ cells develop via a lineage distinct from the T helper type 1 and 2 lineages. Nat Immunol. (2005) 6:1123-32. doi: 10.1038/ni1254

6. Eyerich S, Eyerich K, Pennino D, Carbone T, Nasorri F, Pallotta S, et al. Th22 cells represent a distinct human $\mathrm{T}$ cell subset involved in epidermal immunity and remodeling. J Clin Invest. (2009) 119:3573-85. doi: 10.1172/JCI 40202

\section{AUTHOR INFORMATION}

The author, Wan-Chung $\mathrm{Hu}$, graduated as an MD from National Taiwan University. He then completed his Ph.D. in vaccine science from the Department of International Health, Johns Hopkins University, Bloomberg School of Public Health. The author's Ph.D. thesis was based on host immune responses against malarial infection. He conducted a postdoctoral study on cancer immunotherapy at the Genomics Research Center, Academia Sinica, Taiwan. The author completed his PGY training from Mackay Memorial Hospital and Shin-Kong Memorial Hospital in Taiwan. He has worked as a chief resident at the Department of Clinical Pathology, Far Eastern Memorial Hospital, Taiwan (R.O.C.), for resident training. He is currently a physician-scientist and an attending clinical pathologist at the Division of Clinical Pathology of Taipei Tzu Chi Hospital.

\section{AUTHOR CONTRIBUTIONS}

W-CH solely contributed to the concept, literature search, writing, and final approval of this manuscript.

\section{ACKNOWLEDGMENTS}

The author is thankful for the instructions provided by Professors Alan Scott, Louis August Bourgeois, and Pien-Chien Huang during his Ph.D. study in the Department of International Health, Johns Hopkins University, Bloomberg School of Public Health. The author is also grateful for the guidance from Professors Chi-Huey Wong and Alice Lin-Tsing $\mathrm{Yu}$ in his postdoctoral research at the Genomics Research Center of Academia Sinica, Taiwan. This manuscript has been released as a pre-print at BioRxiv (70).
7. Dominguez-Villar M, Baecher-Allan CM, Hafler DA. Identification of $T$ helper type 1-like, Foxp3+ regulatory T cells in human autoimmune disease. Nat Med. (2011) 17:673-5. doi: 10.1038/nm.2389

8. Luthje K, Kallies A, Shimohakamada Y, Belz GT, Light A, Tarlinton DM, et al. The development and fate of follicular helper $\mathrm{T}$ cells defined by an IL-21 reporter mouse. Nat Immunol. (2012) 13:491-8. doi: 10.1038/ni.2261

9. Collin M, McGovern N, Haniffa M. Human dendritic cell subsets. Immunology. (2013) 140:22-30. doi: 10.1111/imm.12117

10. Lane PJ, McConnell FM, Withers D, Gaspal F, Saini M, Anderson G. Lymphoid tissue inducer cells: bridges between the ancient innate and the modern adaptive immune systems. Mucosal Immunol. (2009) 2:4727. doi: $10.1038 / \mathrm{mi} .2009 .111$

11. Nurieva RI, Chung Y, Martinez GJ, Yang XO, Tanaka S, Matskevitch TD, et al. Bcl6 mediates the development of T follicular helper cells. Science. (2009) 325:1001-5. doi: 10.1126/science. 1176676

12. McCarron MJ, Marie JC. TGF-beta prevents $\mathrm{T}$ follicular helper cell accumulation and B cell autoreactivity. J Clin Invest. (2014) 124:437586. doi: 10.1172/JCI76179

13. Tran TH, Utama FE, Lin J, Yang $\mathrm{N}$, Sjolund AB, Ryder A, et al. Prolactin inhibits BCL6 expression in breast cancer through a Stat5a-dependent mechanism. Cancer Res. (2010) 70:1711-21. doi: 10.1158/0008-5472.CAN-09-2314

14. Scheeren FA, Naspetti M, Diehl S, Schotte R, Nagasawa M, Wijnands E, et al. STAT5 regulates the self-renewal capacity and differentiation of human 
memory B cells and controls Bcl-6 expression. Nat Immunol. (2005) 6:30313. doi: $10.1038 /$ ni1172

15. Verdier F, Rabionet R, Gouilleux F, Beisenherz-Huss C, Varlet P, Muller O, et al. A sequence of the CIS gene promoter interacts preferentially with two associated STAT5A dimers: a distinct biochemical difference between STAT5A and STAT5B. Mol Cell Biol. (1998) 18:5852-60. doi: 10.1128/MCB.18.10.5852

16. Ettinger R, Sims GP, Fairhurst AM R. Robbins, da Silva YS, Spolski R, Leonard WJ, Lipsky PE. $I L-21$ induces differentiation of human naive and memory B cells into antibody-secreting plasma cells. J Immunol. (2005) 175:786779. doi: 10.4049/jimmunol.175.12.7867

17. Pene J, Gauchat JF, Lecart S, Drouet E, Guglielmi P, Boulay V, et al. Cutting edge: IL-21 is a switch factor for the production of IgG1 and IgG3 by human B cells. J Immunol. (2004) 172:5154-7. doi: 10.4049/jimmunol.172.9.5154

18. Gapin L, Development of invariant natural killer T cells. Curr Opin Immunol. (2016) 39:68-74. doi: 10.1016/j.coi.2016.01.001

19. Choi YS, Eto D, Yang JA, Lao C, Crotty S. Cutting edge: STAT1 is required for IL-6-mediated Bcl6 induction for early follicular helper cell differentiation. $J$ Immunol. (2013) 190:3049-53. doi: 10.4049/jimmunol.1203032

20. Schaerli P, Loetscher P, Moser B. Cutting edge: induction of follicular homing precedes effector Th cell development. J Immunol. (2001) 167:60826. doi: 10.4049/jimmunol.167.11.6082

21. Nakayamada S, Kanno Y, Takahashi H, Jankovic D, Lu KT, Johnson TA, et al. Early Thl cell differentiation is marked by a Tfh cell-like transition. Immunity. (2011) 35:919-31. doi: 10.1016/j.immuni.2011.11.012

22. Arrigucci R, Lakehal K, Vir P, Handler D, Davidow AL, Herrera R, et al. Active tuberculosis is characterized by highly differentiated effector memory Th1 cells. Front Immunol. (2018) 9:2127. doi: 10.3389/fimmu.2018. 02127

23. Iezzi G, Boni A, Degl'Innocenti E, Grioni M, Bertilaccio MT, Bellone M. Type 2 cytotoxic T lymphocytes modulate the activity of dendritic cells toward type 2 immune responses. J Immunol. (2006) 177:21317. doi: 10.4049/jimmunol.177.4.2131

24. Gong D, Shi W, Yi SJ, Chen H, Groffen J, Heisterkamp N. TGFbeta signaling plays a critical role in promoting alternative macrophage activation. BMC Immunol. (2012) 13:31. doi: 10.1186/1471-2172-13-31

25. Eberl G, Colonna M, Di Santo JP, McKenzie AN. Innate lymphoid cells. Innate lymphoid cells: a new paradigm in immunology. Science. (2015) 348:aaa6566. doi: 10.1126/science.aaa6566

26. Kosiewicz MM, Nast CC, Krishnan A, Rivera-Nieves J, Moskaluk CA, Matsumoto S, et al. Th1-type responses mediate spontaneous ileitis in a novel murine model of Crohn's disease. J Clin Invest. (2001) 107:695702. doi: 10.1172/JCI10956

27. Allen JE, Sutherland TE. Host protective roles of type 2 immunity: parasite killing and tissue repair, flip sides of the same coin. Semin Immunol. (2014) 26:329-40. doi: 10.1016/j.smim.2014.06.003

28. Klechevsky E, Morita R, Liu M, Cao Y, Coquery S, Thompson-Snipes $\mathrm{L}$, et al. Functional specializations of human epidermal Langerhans cells and CD14+ dermal dendritic cells. Immunity. (2008) 29:497510. doi: 10.1016/j.immuni.2008.07.013

29. Mesnil C, Raulier S, Paulissen G, Xiao X, Birrell MA, Pirottin D, et al. Lungresident eosinophils represent a distinct regulatory eosinophil subset. J Clin Invest. (2016) 126:3279-95. doi: 10.1172/JCI85664

30. Toru H, Eguchi M, Matsumoto R, Yanagida M, Yata J, Nakahata T. Interleukin-4 promotes the development of tryptase and chymase doublepositive human mast cells accompanied by cell maturation. Blood. (1998) 91:187-95. doi: 10.1182/blood.V91.1.187.187_187_195

31. Rodriguez MJ, Aranda A, Fernandez TD, Cubells-Baeza N, Torres MJ, Gomez F, et al. LPS promotes Th2 dependent sensitisation leading to anaphylaxis in a Pru p 3 mouse model. Sci Rep. (2017) 7:40449. doi: 10.1038/srep 40449

32. Loebbermann J, Schnoeller C, Thornton H, Durant L, Sweeney NP, Schuijs $\mathrm{M}$, et al. IL-10 regulates viral lung immunopathology during acute respiratory syncytial virus infection in mice. PLoS ONE. (2012) 7:e32371. doi: 10.1371/journal.pone.0032371

33. Jung U, Foley JE, Erdmann AA, Eckhaus MA, Fowler DH. CD3/CD28costimulated $\mathrm{T} 1$ and $\mathrm{T} 2$ subsets: differential in vivo allosensitization generates distinct GVT and GVHD effects. Blood. (2003) 102:343946. doi: 10.1182/blood-2002-12-3936
34. Peritt D, Robertson S, Gri G, Showe L, Aste-Amezaga M, Trinchieri G. Differentiation of human NK cells into NK1 and NK2 subsets. J Immunol. (1998) 161:5821-4.

35. Kim HS, Jang JH, Lee MB, Jung ID, Kim YM, Park YM, et al. A novel IL-10producing innate lymphoid cells (ILC10) in a contact hypersensitivity mouse model. BMB Rep. (2016) 49:293-6. doi: 10.5483/BMBRep.2016.49.5.023

36. Nguyen KB, Cousens LP, Doughty LA, Pien GC, Durbin JE, Biron CA. Interferon alpha/beta-mediated inhibition and promotion of interferon gamma: STAT1 resolves a paradox. Nat Immunol. (2000) 1:70-6. doi: 10.1038/76940

37. Ueki I, Abiru N, Kawagoe K, Nagayama Y. Interleukin 10 deficiency attenuates induction of anti-TSH receptor antibodies and hyperthyroidism in a mouse Graves' model. J Endocrinol. (2011) 209:353-7. doi: 10.1530/JOE-11-0129

38. Basu R, O'Quinn DB, Silberger DJ, Schoeb TR, Fouser L, Ouyang $\mathrm{W}$, et al. Th22 cells are an important source of IL-22 for host protection against enteropathogenic bacteria. Immunity. (2012) 37:106175. doi: 10.1016/j.immuni.2012.08.024

39. Trifari S, Kaplan CD, Tran EH, Crellin NK, Spits H. Identification of a human helper $\mathrm{T}$ cell population that has abundant production of interleukin 22 and is distinct from $\mathrm{T}(\mathrm{H})-17, \mathrm{~T}(\mathrm{H}) 1$ and $\mathrm{T}(\mathrm{H}) 2$ cells. Nat Immunol. (2009) 10:864-71. doi: $10.1038 /$ ni.1770

40. Walker JA, Barlow JL, McKenzie AN. Innate lymphoid cells-how did we miss them? Nat Rev Immunol. (2013) 13:75-87. doi: 10.1038/nri3349

41. Rutz S, Noubade R, Eidenschenk C, Ota N, Zeng W, Zheng Y, et al. Transcription factor c-Maf mediates the TGF-beta-dependent suppression of IL-22 production in $\mathrm{T}(\mathrm{H}) 17$ cells. Nat Immunol. (2011) 12:123845. doi: $10.1038 /$ ni.2134

42. Zhang L, Li JM, Liu XG, Ma DX, Hu NW, Li YG, et al. Elevated Th22 cells correlated with Th17 cells in patients with rheumatoid arthritis. J Clin Immunol. (2011) 31:606-14. doi: 10.1007/s10875-011-9540-8

43. Hussain R, Dawood G, Abrar N, Toossi Z, Minai A, Dojki M, et al. Selective increases in antibody isotypes and immunoglobulin G subclass responses to secreted antigens in tuberculosis patients and healthy household contacts of the patients. Clin Diagn Lab Immunol. (1995) 2:72632. doi: 10.1128/CDLI.2.6.726-732.1995

44. Coutelier JP, van der Logt JT, Heessen FW, Vink A, and van Snick J. Virally induced modulation of murine IgG antibody subclasses. J Exp Med. (1988) 168:2373-8. doi: 10.1084/jem.168.6.2373

45. Siber GR, Schur PH, Aisenberg AC, Weitzman SA, Schiffman G. Correlation between serum IgG-2 concentrations and the antibody response to bacterial polysaccharide antigens. N Engl J Med. (1980) 303:17882. doi: 10.1056/NEJM198007243030402

46. Turner JD, Faulkner H, Kamgno J, Kennedy MW, Behnke J, Boussinesq $\mathrm{M}$, et al. Allergen-specific IgE and IgG4 are markers of resistance and susceptibility in a human intestinal nematode infection. Microbes Infect. (2005) 7:990-6. doi: 10.1016/j.micinf.2005.03.036

47. Hori S, Nomura T, Sakaguchi S. Control of regulatory $\mathrm{T}$ cell development by the transcription factor Foxp3. Science. (2003) 299:1057-61. doi: 10.1126/science. 1079490

48. Schmidt SV, Nino-Castro AC, Schultze JL. Regulatory dendritic cells: there is more than just immune activation. Front Immunol. (2012) 3:274. doi: 10.3389 /fimmu. 2012.00274

49. Wang S, Xia P, Chen Y, Qu Y, Xiong Z, Ye B, et al. Regulatory innate lymphoid cells control innate intestinal inflammation. Cell. (2017) 171:20116.e18. doi: 10.1016/j.cell.2017.07.027

50. Monteiro M, Almeida CF, Caridade M, Ribot JC, Duarte J, Agua-Doce A, et al. Identification of regulatory Foxp3+ invariant NKT cells induced by TGF-beta. J Immunol. (2010) 185:2157-63. doi: 10.4049/jimmunol.1000359

51. Yao Z, Kanno Y, Kerenyi M, Stephens G, Durant L, Watford WT, et al. Nonredundant roles for Stat5a/b in directly regulating Foxp3. Blood. (2007) 109:4368-75. doi: 10.1182/blood-2006-11-055756

52. Wei HX, Chuang YH, Li B, Wei H, Sun R, Moritoki Y, et al. CD4+ CD25+ Foxp3+ regulatory $\mathrm{T}$ cells protect against $\mathrm{T}$ cell-mediated fulminant hepatitis in a TGF-beta-dependent manner in mice. J Immunol. (2008) 181:72219. doi: 10.4049/jimmunol.181.10.7221

53. Zan H, Cerutti A, Dramitinos P, Schaffer A, Casali P. CD40 engagement triggers switching to IgA1 and IgA2 in human B cells through induction of endogenous TGF-beta: evidence for TGF-beta but not IL-10-dependent direct 
$\mathrm{S}$ mu $->\mathrm{S}$ alpha and sequential $\mathrm{S}$ mu- $>\mathrm{S}$ gamma, $\mathrm{S}$ gamma->S alpha DNA recombination. J Immunol. (1998) 161:5217-25.

54. Prochazkova J, Pokorna K, Holan V. IL-12 inhibits the TGF-betadependent $\mathrm{T}$ cell developmental programs and skews the TGF-beta-induced differentiation into a Th1-like direction. Immunobiology. (2012) 217:7482. doi: 10.1016/j.imbio.2011.07.032

55. Farajnia S, Mahboudi F, Ajdari S, Reiner NE, Kariminia A, Alimohammadian MH. Mononuclear cells from patients recovered from cutaneous leishmaniasis respond to Leishmania major amastigote class I nuclease with a predominant Th1-like response. Clin Exp Immunol. (2005) 139:498-505. doi: 10.1111/j.1365-2249.2004.02702.x

56. Romero P, Zippelius A, Kurth I, Pittet MJ, Touvrey C, Iancu $\mathrm{EM}$, et al. Four functionally distinct populations of human effector-memory CD8+ $\mathrm{T}$ lymphocytes. J Immunol. (2007) 178:4112-9. doi: 10.4049/jimmunol.178.7.4112

57. Gerlach K, Hwang Y, Nikolaev A, Atreya R, Dornhoff H, Steiner S, et al. TH9 cells that express the transcription factor PU.1 drive T cell-mediated colitis via IL-9 receptor signaling in intestinal epithelial cells. Nat Immunol. (2014) 15:676-86. doi: 10.1038/ni.2920

58. Dardalhon V, Awasthi A, Kwon H, Galileos G, Gao W, Sobel RA, et al. IL-4 inhibits TGF-beta-induced Foxp3+ T cells and, together with TGFbeta, generates IL-9+ IL-10+ Foxp3(-) effector T cells. Nat Immunol. (2008) 9:1347-55. doi: 10.1038/ni.1677

59. Goswami R, Jabeen R, Yagi R, Pham D, Zhu J, Goenka S, et al. STAT6dependent regulation of Th9 development. J Immunol. (2012) 188:96875. doi: $10.4049 /$ jimmunol.1102840

60. Licona-Limon P, Arias-Rojas A, Olguin-Martinez E. IL-9 and Th9 in parasite immunity. Semin Immunopathol. (2017) 39:2938. doi: 10.1007/s00281-016-0606-9

61. McNeil HP, Gotis-Graham I. Human mast cell subsets-distinct functions in inflammation? Inflamm Res. (2000) 49:3-7. doi: 10.1007/PL00012386

62. Movahed E, Cheok YY, Tan GMY, Lee CYQ, Cheong HC, Velayuthan RD, et al. Lung-infiltrating $\mathrm{T}$ helper 17 cells as the major source of interleukin$17 \mathrm{~A}$ production during pulmonary Cryptococcus neoformans infection. $B M C$ Immunol. (2018) 19:32. doi: 10.1186/s12865-018-0269-5

63. Fridlender ZG, Sun J, Kim S, Kapoor V, Cheng G, Ling L, et al. Polarization of tumor-associated neutrophil phenotype by TGF-beta: "N1" versus "N2" TAN. Cancer Cell. (2009) 16:183-94. doi: 10.1016/j.ccr.2009.06.017
64. Chen ZM, O'Shaughnessy MJ, Gramaglia I, Panoskaltsis-Mortari A, Murphy WJ, Narula S, et al. IL-10 and TGF-beta induce alloreactive CD4+CD25$\mathrm{T}$ cells to acquire regulatory cell function. Blood. (2003) 101:507683. doi: 10.1182/blood-2002-09-2798

65. Doetze A, Satoguina J, Burchard G, Rau T, Loliger C, Fleischer B, et al. Antigen-specific cellular hyporesponsiveness in a chronic human helminth infection is mediated by $\mathrm{T}(\mathrm{h}) 3 / \mathrm{T}(\mathrm{r}) 1$-type cytokines IL-10 and transforming growth factor-beta but not by a $\mathrm{T}(\mathrm{h}) 1$ to $\mathrm{T}(\mathrm{h}) 2$ shift. Int Immunol. (2000) 12:623-30. doi: 10.1093/intimm/12.5.623

66. Zhao J, Zhao J, Mangalam AK, Channappanavar R, Fett C, Meyerholz $\mathrm{DK}$, et al. Airway memory CD4(+) T cells mediate protective immunity against emerging respiratory coronaviruses. Immunity. (2016) 44:137991. doi: 10.1016/j.immuni.2016.05.006

67. Tulunay A, Yavuz S, Direskeneli H, Eksioglu-Demiralp E. CD8+CD28-, suppressive T cells in systemic lupus erythematosus. Lupus. (2008) 17:6307. doi: $10.1177 / 0961203308089400$

68. Keskin DB, Allan DS, Rybalov B, Andzelm MM, Stern JN, Kopcow HD, et al. TGFbeta promotes conversion of CD16+ peripheral blood NK cells into CD16- NK cells with similarities to decidual NK cells. Proc Natl Acad Sci USA. (2007) 104:3378-83. doi: 10.1073/pnas.0611098104

69. Ishida H, Muchamuel T, Sakaguchi S, Andrade S, Menon S, Howard M. Continuous administration of anti-interleukin 10 antibodies delays onset of autoimmunity in NZB/W F1 mice. J Exp Med. (1994) 179:30510. doi: $10.1084 /$ jem.179.1.305

70. Hu WC. A framework of all discovered immunological pathways and their roles for four specific types of pathogens and hypersensitivities. BioRxiv. (2020). doi: 10.1101/006965. [Epub ahead of print].

Conflict of Interest: The author declares that the research was conducted in the absence of any commercial or financial relationships that could be construed as a potential conflict of interest.

Copyright $\odot 2020 \mathrm{Hu}$. This is an open-access article distributed under the terms of the Creative Commons Attribution License (CC BY). The use, distribution or reproduction in other forums is permitted, provided the original author(s) and the copyright owner(s) are credited and that the original publication in this journal is cited, in accordance with accepted academic practice. No use, distribution or reproduction is permitted which does not comply with these terms. 